\title{
XXXIV. On a new oxalate of chromium and potash
}

\section{Henry Croft Esq.}

To cite this article: Henry Croft Esq. (1842) XXXIV. On a new oxalate of chromium and potash , Philosophical Magazine Series 3, 21:137, 197-200, DOI: 10.1080/14786444208621519

To link to this article: http://dx.doi.org/10.1080/14786444208621519

册 Published online: 01 Jun 2009.

Submit your article to this journal 준

Џ Article views: 3

Q View related articles $₫$ 
Mr. Croft on a new Oxalate of Chromium and Potash. 197

imagination can conceive: the red crystals do not appear to be affected by polarized light, so far as the display of colour is concerned.

The magnifying powers used in these investigations were, for the experiments on the sublimed crystals, 200 times linear measurement or diameters; in the precipitated compound, 620 diameters.

XXXIV. On a new Oxalate of Chromium and Potash. By Henry Croft, Esq.*

T $\mathrm{T}$ is well known that in 1830 Wilton ' $\Gamma$ umer accidentally 1 discovered a salt composed of oxalate of the oxide of chromium and oxalate of potash. Its curious optical properties have been examined by Brewster $\uparrow$. Gregory also discovered the same salt independently, and proposed a much better method for obtaining it than that used by Turner, which consisted in adding oxalic acid to a solution of bichromate of potash until effervescence ceased: the solution became deep green or black, and on evaporation yielded beautiful crystals of the black salt. Gregory supposed it to consist of 3 equivalents of oxalic acid, 2 of potash, 1 of oxide of chromium, and 6 of water. Its true composition, $3\left(\mathrm{KO}, \mathrm{C}_{2} \mathrm{O}_{3}\right)+\mathrm{Cr}_{2} \mathrm{O}_{3}$, $3 \mathrm{C}_{2} \mathrm{O}_{3}+6 \mathrm{HO}$ has been shown by Graham and Mitscherlich, who have also prepared a number of salts similarly constituted.

On attempting to prepare the black salt by Turner's method I could never completely succeed, but obtained in its stead, when a very concentrated hot solution of the bichromate was employed, a red granular precipitate, which proved to be a new salt, and forms the subject of the present notice.

Perhaps the best method of preparing it is that above described, viz. to employ as concentrated a solution of the bichromate as possible, in which case the salt crystallizes out on cooling. The precipitated salt must be redissolved in a small quantity of water and allowed to crystallize. It is however one of the most difficult salts to crystallize that is known : in nine cases out of ten it separates in the form of a somewhat granular bluish gray powder, and it appears to be only under particular circumstances that it will crystallize well, which, however, I was not able to discover. It does not seem to

* Communicated by the Chemical Society, having been read February 15 , 1842.

[ + See Phil. Mag. Third Series, vol. vii. p. 436. Some of the optical and crystallographical properties of this salt have also been described by $\mathrm{Mr}$. Talbot, in Phil. Mag. Third Series, vol. x. p. 218, and yol, xiv. p.21.Emit.] 


\section{$198 \mathrm{Mr}$. Croft on a nerv Oxalate of Chromium and Potash.}

crystallize any better by spontaneous evaporation than out of a very concentrated solution; it seems however to form more regularly in warm air, as in summer. The best crystals are generally formed on the surface of the solutions: they are very minute, in the form of triangular plates; when the crystals form a mass at the bottom of the liquid the plates are thicker, but their form is indistinguishable. The salt is of a deep red colour by reflected as well as by transmitted light; the solution is green, or even black (when concentrated) by reflected and red by transmitted light. The solution when at a boiling temperature remains red, as is seen best by candlelight: the same is the case with the solution of the black salt, which shows that the purple oxide of chromium contained in these salts is not converted by a boiling heat into its green modification; the purple oxide must, however, as is well known, be first brought into combination with the oxalic acid, for the black salt can never be obtained by dissolving green oxide of chromium in binoxalate of potash.

A solution of caustic potash added to a solution of the red salt turns it bright green, but causes no precipitate until boiled, when the greater part of the oxide of chromium is thrown down. Carbonates of the alkalies partly change the colour in the same manner, but do not precipitate the oxide so readily. Ammonia causes no precipitate, nor does chloride of calcium, owing to the formation of Dingler's oxalate of chromium and lime; when ammonia is added a green precipitate containing oxide of chromium is formed.

This salt contains a large quantity of water of crystallization, which can only be driven out by a strong heat, as is also the case with the black salt (Graham). It loses about 15-16 per cent. at $100^{\circ}$ cent., and 19 per cent. at $200^{\circ}$ cent. The last portions of water can only be driven out at $300^{\circ}$ cent. Near this point the salt begins to be decomposed, and consequently the determination of the water is rendered somewhat difficult.

0.9986 gramme of salt lost 0.2638 water $=26.42$

$0.7481 \quad \ldots \quad \ldots \quad 0.1965 \quad \ldots=26.27$

$0.8971 \quad \ldots \quad \ldots \quad \ldots \quad 0.2532 \ldots=28.22$

The determinations of the oxide of chromium and the potash were performed in the following manner. The salt was heated red-hot: in this operation great care must be taken, for the salt possesses the curious property of decomposing with considerable violence (without explosion) into a green powder, which unless the heat is applied very gradually, is forced out of the crucible, and the analysis is thus lost. When the temperature is raised gradually the crystals retain their 
form, but become of a bright dark green colour : as soon as the decomposition of the oxalates commences they fall into a light green powder, which when stronger heated becomes brown. In closed vessels carbonate of potash is formed; in open ones, when the heat is continued for a length of time, chromat: $\mathrm{is}$ produced. This chromate must be extracted by water, reduced, and the oxide of chromium precipitated by ammonia : in this operation, however, it is better to evaporate the ammoniacal solution to dryness, as the ammonia always dissolves a small quantity of the oxide. This method is preferable to that usually employed (Heinrich Rose's Analytical Chemistry) : the ammoniacal and potash salts must be dissolved out, evaporated, the ammonia driven off, and the potash determined either as chloride or by means of platinum.

The oxalic acid may be determined by boiling the salt with sulphuric acid, as proposed by Prof. Graham.

The salt being excessively difficult to crystallize, it seldom happens that a perfectly homogeneous substance can be obtained for analysis : the method of analysis is moreover somewhat complicated, and consequently the analyses do not agree so perfectly as could be desired.

\begin{tabular}{lcccccc} 
& I. & II. & IIr. & IV. & V. & vi. \\
$\mathrm{Cr}_{2} \mathrm{O}_{3} 21 \cdot 80$ & $21 \cdot 83$ & $23 \cdot 11$ & $22 \cdot 05$ & $21 \cdot 10$ & $24 \cdot 11$ \\
$\mathrm{KO}_{3}$ & $13 \cdot 18$ & $13 \cdot 11$ & $12 \cdot 22$ & $12 \cdot 92$ & & \\
$\mathrm{C}_{2} \mathrm{O}_{3}$ & $37 \cdot 00$ & $36 \cdot 98$ & \\
\multicolumn{7}{c}{ The water as obtained by other experiments, is }
\end{tabular}

$$
\begin{array}{llll}
\mathrm{HO} & 26.42 & 26 \cdot 27 & 28 \cdot 22
\end{array}
$$

The most plausible formula is $\mathrm{KU}, \mathrm{C}_{2} \mathrm{O}_{3}+\mathrm{Cr}_{2} \mathrm{O}_{33} 3 \mathrm{C}_{2} \mathrm{O}_{3}$ $+12 \mathrm{HO}$.

$$
\begin{array}{lrrr}
\mathrm{C}_{2} \mathrm{O}_{3} & 4 & 1811 \cdot 50 & 38 \cdot 098 \\
\mathrm{Cr}_{2} \mathrm{O}_{3} & 1 & 1003 \cdot 63 & 21 \cdot 107 \\
\mathrm{~K} \mathrm{O} & 1 & 589 \cdot 92 & 12 \cdot 405 \\
\mathrm{H} \mathrm{O} & 12 & \frac{1349 \cdot 75}{4754 \cdot 80} & \frac{28 \cdot 390}{100 \cdot 000}
\end{array}
$$

This differs from the black salt in containing one atom of basic oxalate instead of three. It may be said to be related to the black salt in the same way as metaphosphates are to phosphates. It is evident, therefore, that if we add two atoms of oxalate of potash to one atom of the red salt, we ought to obtain the black salt, which is indeed the case.

2.37 grammes of red salt were mixed with $1 \cdot 15 \mathrm{gr}$. of oxalate of potash (these are the atomic proportions), the solution boiled and evaporated, they yielded 3.119 grs. of the black salt in good crystals, and perfectly pure : according to theory it ought to have given $3 \cdot 070$. The weight of the black salt must be equal to that of the red salt, plus two atoms of anhy- 


\section{Mr. Croft on a new Oxalate of Chromium and Potash.}

drous oxalate of potash, minus six atoms of water. The agreement of the experiment with the calculation speaks for the correctness of the above formula, in which one might, perhaps, otherivise not place so much confidence.

The constitution of this salt led me to consider the theory of its formation, and also that of the black salt, more particularly as in employing the known formulæ for making the black salt I always obtained it mixed with other bodies.

In forming the red salt from bichromate of potassa, 7 atoms of oxalic acid are required. $\mathrm{K} \mathrm{O}, 2 \mathrm{Cr} \mathrm{O}_{3}$ and $7 \mathrm{C}_{2} \mathrm{O}_{3}=$ $\mathrm{K} \mathrm{O}, \mathrm{C}_{2} \mathrm{O}_{3}+\mathrm{Cr}_{2} \mathrm{O}_{3}, 3 \mathrm{C}_{2} \mathrm{O}_{3}$ and $3 \mathrm{C}_{2} \mathrm{O}_{3}+3 \mathrm{O}$, or $6 \mathrm{C} \mathrm{O}_{2}$. On mixing the two substances in this proportion $I$ obtained perfectly pure red salt. It is evident that seven atoms of oxalic acid, either free or in combination with potash, must be used in making the black salt. None of the numbers in the formulæ given for preparing the black salt agree with this.

Dr. Gregory gives 190 parts bichromate of potash, 157.5 parts crystallized oxalic acid, and 517 parts binoxalate of potash; that is, one atom of the bichromate, two atoms oxalic acid, and three of binoxalate of potash ; on trying these numbers I obtained a mixture of black salt with oxalate and chromate of potash.

Prof. Graham proposes one part of bichromate, two of binoxalate, and two of crystallized oxalic acid. In these proportions a large quantity of chromate of potassa remains undecomposed, which requires, if 19 grains bichromate, 23 grains binoxalate, and 16 grains crystallized oxalic acid be taken, exactly 36 grains of crystallized oxalic acid to effect its perfect decomposition, and making the whole quantity of oxalic acid 52 grains.

According to the formula which I would propose, there are required

\section{9 grains bichromate of potash}

23 ... oxalate of potash

55 -... crystallized oxalic acid.

If the salts be taken in these proportions, nothing but black salt is obtained; it is however better to evaporate the whole to dryness and then re-dissolve.

I have not been able to obtain an intermediate salt, namely, $2 \mathrm{~K} \mathrm{O}, \mathrm{C}_{2} \mathrm{O}_{3}+\mathrm{Cr}_{2} \mathrm{O}_{3}, 3 \mathrm{C}_{2} \mathrm{O}_{3}$. This, if it exists, ought to be produced from two atoms chromate of potash, and eight atoms oxalic acid : I obtained, however, oxalate of potash and red salt.

A simiar salt may probably exist with oxide of iron, but it does not crystallize. On dissolving sesquioxide of iron in quadroxalate of potash a solution is obtained, which dries to a brown gummy mass without traces of crystallization. 